\title{
Três variantes sobre um tema eterno
}

\section{Inscrição}

o poeta inscreve

no cristal vivo dos teus olhos

a breve palavra amor

o vento vem

e apaga

$|11.10 .1993|$

Amor em tempos de crise

para José Paulo Paes

o amor eterno

- aquele que durava a vida inteira

e ainda pedia mais tempo para amar foi despedido!

$|2031999|$

Pedaços

pedaços de ti

ficaram brilhando

em meus olhos 